\title{
A Mérei-féle csoportcentrikus pszichodráma mint szociodráma
}

\author{
BLASKÓ ÁGNES ${ }^{1}$ - PADOS ESZTER ${ }^{2}$
}

\begin{abstract}
ABSZTRAKT
Tézisünk szerint a pszichodrámaként elterjedt Mérei-féle csoportcentrikus pszichodráma társadalmi problémák kezelésére is alkalmas módszer, csak ez a lehetőség, elsősorban társadalomtörténeti okokból, nem forrhatta ki magát. Cikkünkben meghatározzuk a társadalmi kérdésekkel foglalkozó csoportmódszer, a szociodráma differentia specifikáját, majd annak alapján elemzünk két Mérei-módszerrel vezetett csoportcentrikus pszichodráma ülést, hogy megfigyeljük, a benne alkalmazott technikák milyen változtatásokkal lehetnek alkalmasak szociodráma vezetésére. Eredményeink a Szociodráma Mühelyünk folyamatos módszertani kísérletező munkájában születtek.
\end{abstract}

KULCSSZAVAK: szociodráma, Mérei, csoportcentrikus pszichodráma, kritikai terápia, pszichológiatörténet

\section{ABSTRACT}

\section{Merei's Group-centered Psychodrama as Sociodrama}

According to the authors, Mérei Ferenc's method of group-centric psychodrama can also be used for managing social problems. However, this possibility mentioned above was not fully developed, primarily due to social-historical reasons. In this article the specificity of sociodrama, and the analysis of differentia specifica of sociodrama are defined. Based on the findings, two group-centric psychodrama sessions lead with Mérei-method are analysed to identify the possible changes of techniques necessary to transform the session into sociodrama. Results were born in the Hungarian Sociodrama Methodological Working Group.

KEYWORDS: sociodrama, Mérei, group-centric psychodrama, critical therapy, history of psychology

${ }^{1}$ Budapesti Műszaki és Gazdaságtudományi Egyetem, Szociológia és Kommunikáció Tanszék, egyetemi adjunktus.

${ }^{2}$ Eötvös Loránd Tudományegyetem Pszichológiai Intézet, Eötvös Loránd Tudományegyetem Pszichológiai Doktori Iskola hallgatója, EMMI Budapesti Javítóintézet munkatársa. 


\section{TEMATIKUS TANULMÁNYOK - Pszi-komplexum}

\section{Bevezető}

A pszichodráma az akcióorientált pszichoterápiák bevett, Magyarországon igen elterjedt típusa. Noha a szakma több képviselője is alapvetően a pszichoterápiás és önismereti célra használt pszichodrámát ismeri és ismeri el, a harmad-negyed generációs pszichodramatisták egyre gyakrabban alkalmazzák újabb és újabb, nem „pszicho" területeken (pl. szervezetfejlesztésre, múzeumi vezetésre stb.).

A különböző nyilvános társadalmi terekben alkalmazott dráma vagy azt állítja magáról, hogy képes megtartani (holding) a csoporttagok intrapszichés eseményeit (függetlenül az aktuális dráma rendhagyó körülményeitől), vagy olyan vezetést igényel, ami deklaráltan társadalmiként képes értelmezni az akcióban születő jelentéseket, azaz ez utóbbi esetben valójában szociodráma.

Paradox módon ezeknek az egyre szaporodó szárnypróbálgatásoknak sokkal komolyabb alapja van, mint az a jelenlegi pszicho-perspektívából látszik, és mint aminek a vezetők valójában tudatában vannak (sokkal inkább csak érzik a módszer más területeken is kezes voltát). A hazai pszichodráma egyik gyökere a Mérei Ferenc-féle „csoportcentrikus pszichodráma” (amely máig a két-három nagyobb létező pszichodráma iskola egyike Magyarországon) ugyanis erős társadalomkritikai térben született. Aminek egyszersmind az lehet a következménye, hogy kellő tudatossággal vezetve a Mérei-féle pszichodráma a szociodráma egyik alapvető típusaként is múködtethető. Azaz állításunk szerint az évtizedekig pszichoként (el)ismert módszer úgy tűnik, lényegénél fogva képes arra, hogy társadalomelméletileg megfelelően felvértezett vezetők kezében szociodrámává váljon, az interperszonális problémákon túlmutatva beavatkozzon a csoportos és társadalmi jelenségek kezelésébe. A szociodráma tehát olyan dramatikus akció-módszer, amely az interperszonálisként definiált problémák társas, társadalmi vonatkozásaira kérdez és mutat rá, és amelynek kezelésére hivatott.

Cikkünkben ehhez először vázoljuk a hazai, Mérei-féle csoportcentrikus pszichodráma születésének néhány par excellence társadalmi vonatkozását, majd ismertetjük a szociodráma általunk felállított differentia specifikáját, a szociodráma társadalmi jelentéskonstruáló képességét. Végül megvizsgáljuk, hogy a jelenleg Mérei-féle csoportközpontú pszichodrámaként ismert módszer milyen szemléletű vezetésben válhat a szociodráma egyik típusává.

\section{Pszichodráma: csoportcentrikus módszer a Kádár-korszakban}

A Jacob Levy Moreno nevéhez füződő pszichodráma a hetvenes évek elején indult útjára „intézményesen” Magyarországon, azaz Mérei Ferenc akkor indította el Mű- 


\section{TEMATIKUS TANULMÁNYOK - Pszi-komplexum}

helycsoportját (továbbiakban: M.Cs.) olyan csoporttagokkal, ${ }^{3}$ akik közül néhányan már korábban találkoztak a módszerrel (Ajtony 2006). A Kádár-korszakban Magyarországon Mérei bábáskodásával született módszer specifikumait érdemes kontextusában is vizsgálni, a módszer szociodrámaként való részletes elemzése előtt. Mert noha a Mérei-féle csoportcentrikus pszichodráma pszichodrámaként terjedt el, egyrészt erősen táplálkozik a Moreno-féle szociodrámából is, másrészt pedig olyan társadalmi közegben alakította ki Mérei, amely önmagában óhatatlanul rávetül magára a módszerre.

J. L. Moreno tehát a szocio- és a pszichodráma kitalálója is egyben. Mérei a Mühelycsoportban alapvetően a pszichodráma módszert fejlesztette, miközben a posztumusz megjelent, Bagdy Emőke által szerkesztett kötetében, A pszichológiai labirintusban, a két műfaj között mindössze tartalmi különbséget tesz: a szociodrámát politikai és társadalmi problémákat megdolgozó műfajnak tekinti, a pszichodrámát pedig személyközpontúnak. A tartalmi különbségtétel után egyenesen úgy fogalmaz, hogy a szociodráma és a pszichodráma „a mai gyakorlatunkban összefolyik” (Mérei 1989: 142), hiszen a különbség csak abban rejlik, hogy a konfliktust a vezető az absztrakció vagy a konkrét élmény felé viszi. Méreinek ez a gondolata - noha nem értünk vele egyet, mert szerintünk ma a két módszer között pontos vonal húzandó ${ }^{4}$ - bennünket abban erősít meg, hogy Mérei sajátos módszertanában immanensen vannak jelen az általunk szociodramatikusként aposztrofált elemek.

És valóban, az, amit ma Mérei-féle csoportcentrikus pszichodrámaként ismerhetünk, a társas dimenziót, illetve az egyén tágabb környezetét nemcsak beemeli a pszichodráma keretei közé, hanem erősen arra is fókuszál - köszönhetően a társadalmi közegnek is.

Ugyanis Mérei Ferenc figyelmének középpontjában mind elméleti munkásságában, mind élettörténetében a kiscsoport állt. Olyan időszakban, közegben és olyan attitűddel élt, aminek köszönhetően az életvilág egyes részeinek élhetővé, olykor akár művészivé formálásának (Havasréti 2006) lehetősége egy tágabb, diktatórikus kereten belül történhetett csak meg. Valódi, intézményes közegekből (egyetemi katedra, Gyermeklélektani Intézet, Szociológiai Intézet) kizárják, ám épp a mindenkori aktuális ki- vagy adott esetben elzárás okán és ellenében teremtődik vagy hozható létre élhető tér. Mozgalmár tapasztalatai, az avantgárdhoz való ellenállhatatlan vonzódása, barátaiból álló sajátos szubkultúrát létrehozó vagy éppen szakmai csoportjai (a „Törzs”, „M.Cs.”) (Havasréti 2006, Mérei 1989, Bagdy 2006, K. Horváth 2006), rabtársaira nagy hatással lévő börtönélete (Litván 2006), illetve az ezekből és itt

${ }^{3}$ Ajkay Klára, Bagdy Emőke, Dobos Emőke, Erdélyi Ildikó, Láng Iringó, Pál Mária, valamint Kapusi Gyula, Pajor András, Falus Ferenc, Forgács Péter.

${ }^{4}$ Vö. alább: 2 . A közös társadalmi jelentés meghatározása c. rész. 


\section{TEMATIKUS TANULMÁNYOK - Pszi-komplexum}

született munkái mind-mind az egyén csoportos tereinek megteremtéséről és az abban való eligazodásról szóltak - a tágabb, társadalmi közeg ellenében.

Amikor tehát a hetvenes években elindul a pszichodráma Műhelycsoport, akkorra a csoportról mint formáról sokrétű elméleti és gyakorlati tapasztalata van Mérei Ferencnek, és nem kérdés, hogy ezt tekinti az emberi-társas-társadalmi működés alapvető formájának. Az e közegben kialakuló módszer társadalomtörténeti szempontból mindenképpen áttételesen átpolitizált.

Összességében tehát úgy látjuk, hogy olyan társadalmi térben rajzolódik és hozza létre azt a pedagógiai-pszichológiai gondolkodást Magyarországon Mérei Ferenc, ahol éppen az önmagunk megtalálása a cél az intézményrendszerekkel szemben.

Az elmúlt évtizedekben azonban a közeg erősen átalakult, az esetleges társadalmi áthallások háttérbe szorultak, és maga a pszichodráma módszer - egyéb pszicho-módszerekkel karöltve pedig szűk körök kiváltságává alakul, ahogyan ezt a kritikai pszichológiai gondolkodás (Kovai 2016, Gergely 2018) egyre részletesebben igyekszik felszínre hozni.

Ha tehát a szociodráma módszertanát és elméletét kívánjuk újragondolni, akkor a fentiek alapján mindenképp érdemes a Mérei-féle csoportcentrikus pszichodráma módszert is számításba venni.

\section{A szociodráma differentia specifikája: a közös társadalmi jelentés ${ }^{5}$}

2016 végétől a Magyar Pszichodráma Egyesülettel (MPE) együttműködő szociodráma műhelyünk ${ }^{6}$ a nemzetközi PERFORMERS ${ }^{7}$ projektünkkel megtámogatva elkezdte újra intézményesen feléleszteni a szociodrámát a hazai közegben. Múhelyünk szisztematikus elméleti és gyakorlati adaptálásnak, illetve kidolgozásnak látott neki. A folyamat során jutottunk el Mérei Ferenc csoportcentrikus pszichodrámájának vizsgálatához, mert úgy láttuk, hogy vélhetőleg a Mérei Ferenc-féle csoportcentrikus pszichodráma a szociodráma jól körülhatárolható típusaként azonosítható - mini-

${ }^{5}$ Ebben a részben a gondolatmenetünkhöz szükséges főbb téziseinket ismertetjük, de e cikk keretei nem teszik lehetővé az állítások részletes kifejtését, így azokat későbbi tanulmányokban tervezzük közzétenni.

${ }^{6}$ A módszertani összehasonlítás kezdeményezését és vizsgálatát a szociodráma műhely tagjai végezték, akik a szociodráma módszerének szisztematikus kidolgozására hivatottak. A csoport tagjai: Blaskó Ágnes, Durst Mónika, Galgóczi Krisztina, Horváth Kata, Kocsi Andrea Zsuzsanna, Pados Eszter, Tóth Attila.

${ }^{7}$ A P.E.R.F.O.R.M.E.R.S. projekt az Erasmus+ Stratégiai Partnerségek Program keretében és finanszírozásában valósult meg. Négy európai ország négy pszichodráma szervezete és négy hátrányos helyzetű fiatalokkal foglalkozó intézménye múködött együtt. A projekt többek között nemzetközi tudásmegosztásról és helyi fejlesztésekről szólt. Lásd bővebben: Blaskó, Á. - Horváth, K. - Pados, E. (2017): Társadalmi felelősség, módszer, aktivizálás. Szociodráma Európában hátrányos helyzetü fiatalokkal és segítőikkel. Pszichodráma, A Magyar Pszichodráma Egyesület folyóirata, 2017. ősz. 


\section{TEMATIKUS TANULMÁNYOK - Pszi-komplexum}

mális módszertani, technikai változtatásokkal, de paradigmatikus szemléletmódváltással.

Ekkorra már azzal a közösen kidolgozott előfeltevéssel dolgoztunk, miszerint a szociodráma differentia specifikája a pszichodrámához képest a közös társas, társadalmi jelentés születése. E meghatározásból a közös jelentés és a társadalmi fogalmát is fontos tisztázni.

A közös jelentés konstruálódása azért alapvető eleme a szociodrámának, mert szemben a pszichodrámával - a csoport közös mentalizálása (Krüger 2017) a cél legyen szó akár a probléma feltérképezésről, konfliktusmegoldásról, vízióalkotásról vagy szupervízióról. A szociodráma ugyanis egy közösség problémájával foglalkozik, amelyre természetesen születhetnek egyéni válaszok, megoldási stratégiák, de minimum a probléma detektálásának szintjén fontos az együttes megértés, belátás megszületése. Enélkül ugyanis az önismereti hozadéka marad előtérben a dráma ülésnek, hiszen azt tanulhatja meg a résztvevő, hogy egy adott társas vagy társadalmi kontextusban milyen személyes szerepvállalásra képes és miért, illetve hogyan tud azon alakítani. A szociodráma célja azonban a közös társas, társadalmi problémák feltárása és azok (kompetenciáján belüli) kezelésének megkezdése új jelentéskonstrukciók létrehozásával. A közös jelentés tehát feltételezzük, olyan, a csoportmunkában explicite konstruálódó jelentés, amely a közösség számára újszerü felismerést hoz, amely új módon rendezi a közös tudást.

Önmagában tehát egy játék közben vagy a sharingben (játék utáni megosztás) elhangzó jelentés hiába explicit, még nem tekinthető közösnek. Akkor válik a jelentés közössé, ha az például:

- nyilvánvalóan meghatározza, befolyásolja a játék/az ülés egészének irányát; (Így például abban a vizsgált nagycsoportunkban, amelyben a „Hogyan vagyunk így együtt?" kérdésre végül a deportálás előtt álló zsidók egy napját játssza el a csoport, nyilvánvaló, hogy a csoport beleegyezett a klíma abbéli interpretációjába, hogy a jelenlegi helyzet/közérzet és a deportálás előtti állapot sok ponton azonosítható.)

- a csoport explicit témájává válik;

- sokan csatlakoznak a sharing körben az adott jelentéshez;

- közös munka, gondolkodás kezdődik az adott kérdésben; (Így például, amikor a múhelycsoportunk egy adott politikai helyzet megoldására kereste a választ, a problémamegoldás vágya tartalmazta azt a közös értékítéletet, miszerint a résztvevők az adott politikai helyzetet problémásnak érzékelik.)

- a tagok nagy része például utólagos megkérdezés után beszámol az adott jelentés megszületéséről. 


\section{TEMATIKUS TANULMÁNYOK - Pszi-komplexum}

Társadalminak akkor tekinthetjük a közös jelentést, ha az az intrapszichés és az interperszonális szinten kívüli szintek valamelyikére fókusz kerül. Azaz, ha egyértelműen csoportműködési, intézményi vagy társadalmi problémákon dolgozik a drámaesemény. Ez az öt szint - intrapszichés, interperszonális, csoporton belüli, intézményi (csoportközi) és kulturális (társadalmi) - a dramatista diskurzussal összhangban követi az emberi létezés komplexitási szintjeit, noha olykor bio-pszichológiai (Blatner 2011) és metafizikai (kozmikus) szintet (Zuretti 2011, Lindqvist 2005) is szokás beemelni a diskurzusba.

Az egyes szintek természetesen nem határolhatók el minden esetben egyértelműen, de az, hogy mennyire kerültek fókuszba az egyes eseményeken, viszonylag jól meghatározható. Így például csoportműködési problémaként jelenhet meg egy diszfunkcionális hierarchikus szerveződő, munkára szerződött csoport működése, és a drámaesemény fókuszában a pozíciók és a jogosultságok feltárása lehet a középpontban, miközben természetesen az intézményrendszer egészének diszfunkcionalitása is feltárulhat csakúgy, mint a társadalmi tudás a hierarchikus szerveződés mibenlétéről.

Összességében tehát a szociodrámában társadalminak tekintjük a csoporton belüli, az intézményi és a kulturális probléma fókuszt is.

\section{Az elemzési szempontok - az ülések szerkezete}

Miután tehát kapcsolatot láttunk a Mérei-féle csoportcentrikus pszichodráma és a szociodrámáról gondoltak között, Szociodráma Műhelyünkkel részt vettünk két csoportcentrikus pszichodráma alkalmon, majd közösen végigelemeztük, hogy a közös társadalmi jelentések születését a módszer mennyiben (milyen elemekkel, technikákkal) képes biztosítani. Az alábbiakban ezeket a szakmai-technikai eredményeinket közöljük úgy, hogy azok a dráma iránt érdeklődő szakemberek számára a konkrét ülések tartalmi ismertetése nélkül is érthetőek legyenek.

Az első csoportalkalmat Mérei Zsuzsa, pszichodráma vezető, Mérei Ferenc lánya vezette kifejezetten a Mühelytagok számára ${ }^{8}$, az utóbbit Ajkay Klára, egykori M.Cs. tag, kiképző pszichodráma pszichoterapeuta, szupervízor és Kökény Veronika kiképző pszichodráma pszichoterapeuta, szupervízor vezette az MPE Szakmai estjeinek keretén belül „Szakmai est a csoportjátékról” címmel. ${ }^{9}$ Amíg a Mérei Zsuzsa-féle csoportot kifejezetten mühelyünk számára szerveztük, így a résztvevők ismerték egymást; addig az utóbbi csoport nagycsoport volt, és a Magyar Pszichodráma Egyesület minden tagja számára elérhető, tagjai lazán kapcsolódtak egymáshoz. Az ese-

\footnotetext{
${ }^{8}$ 2017. október 20. 13:00-16:00, Auróra.

${ }^{9}$ 2017. november 17.17.00-20.00, Köz-hely.
} 


\section{TEMATIKUS TANULMÁNYOK - Pszi-komplexum}

ményeket a helyszínen jegyzőkönyvben rögzítettük, majd a Műhelyünk által fejlesztett szociodramatikus folyamatelemzésse ${ }^{10}$ elemeztük.

Az alábbiakban e munka és a szakirodalom feltérképezése eredményeként számba vettük az esetlegesen létrejött közös társadalmi jelentéseket megfigyeltük, hogy azok a csoportnyilvánosságba kerültek-e, és megvizsgáltuk a létrejöttüket biztosító technikákat.

Az elemzés megkezdése előtt elsőként a két esemény szerkezetét rekonstruáltuk, majd megnéztük, hogy mely elemek biztosították vagy biztosíthatták volna - előfeltevésünkkel összhangban - a közös társadalmi jelentés születését.

Megállapítottuk, hogy mindkét esemény: ${ }^{11}$

- jellegzetes Mérei-féle módszerrel, az ún. „buggyantás” technikájával hozta felszínre a csoport közös, valódi megdolgozandó témáját;

- majd ahhoz keresett egy analóg, játékba fordítható, színre vihető fiktív szituációt;

- majd a színpadon kiépítette a kezdő képet;

- és különböző dráma technikákkal (reflektor, időugratás, interjú) vezette le a játékot.

Végül zárásként saját szerep megélésére, egyéni belátásokra kérdezett rá (megvalósítottad-e a szerepedben, amit szerettél volna; tudod-e, hogy mit szerettél volna kipróbálni a szerepformálásoddal).

\section{Elemzési szempontok - a közös társadalmi jelentések születését biztosító technikák}

Előfeltevéseink szerint akkor tekinthetjük az eseményt szociodrámának, ha a konstruálódó jelentések valóban közössé válnak. Noha a téma mindkét általunk vizsgált ülésen egyértelműen társadalmi volt, kevés eszköz szolgálta azt, hogy a feldolgozásból származó tanulságok valóban közössé is váljanak. (Ne feledjük, a Mérei Ferenc-féle módszer csoportcentrikus pszichodráma, nem szociodráma, tehát mai formájában semmi esetre sem elsődleges célja az, amit számonkérünk rajta. A kérdésfelvetésünk éppen az, hogy tekinthető-e, vagy átalakítható-e a Mérei-féle pszichodráma a szociodráma egyik típusának.)

${ }^{10}$ A szociodráma módszertani fejlesztésünk keretében készülő diary form, három szinten elemzi a dráma alkalom folyamatát: 1 . rész: az adott alkalomra vonatkozó alapvető információkat tartalmazza (résztvevők száma, helyszín, körülmények stb.) A 2. rész: a drámafolyamat részletes leírása, a dráma felépítését követve (bejelentkező kör, bemelegítés, akció megosztás és reflexió, zárás), 9 szempont mentén (pl.: instrukciók, reflexiók, fordulópontok, csoportdinamika). A 3. rész az adott alkalom értelmezései, a folyamat elemzése kerül rögzítésre.

${ }^{11}$ Összhangban az Erdélyi Ildikó által, a Mérei-féle drámákról rögzítettekkel (Erdélyi 2006). 


\section{TEMATIKUS TANULMÁNYOK - Pszi-komplexum}

\section{A folyamatanalízis mint a közös társadalmi jelentés konstruálódásának fó tere}

Először vegyük a folyamat során a legutolsó mozzanatot: a játék értelmezését. A csoporttagok körben ülnek és a vezető által megadott szempontból feltárják a megélteket. A Mérei-féle csoportcentrikus pszichodrámában az egyéni szerepvállalásokra való reflexiók után a csoportdinamika és a játék dinamikájának összekapcsolására hívja a vezető a tagokat (Erdélyi 2006) például a „Mit gondoltok, mi történt?” típusú kérdéssel, amely folyamatanalízisre szólít. A kérdés jelentősége szociodramatista szempontjából, hogy egyrészt biztosítja a fent leírt kritériumok közül a csoportfolyamat értelmezésének explicit megjelenését az ülés alatt, másrészt komoly lehetőséget kínál a közös jelentés születésére, hiszen olyan szituációban történik, amikor szemben a játékkal - biztosan nincsenek párhuzamos események a csoportban, tehát egy beszélő van, akire a többiek odafigyelnek, amikor már nem az akcióé, hanem az interpretációé a szerep. Ráadásul mindez olyan kiemelt helyen van - záráskor - az ülés egészében, amelyre a résztvevők az egyik legnagyobb eséllyel emlékeznek vissza.

A Szociodráma Műhelyünk által vizsgált két csoportcentrikus pszichodrámán a folyamatanalízis idő hiányában elmaradt. A záró kérdés mindkét esetben a privát felé vitte az értelmezés megkezdését. Mérei Zsuzsa arra kérdezett rá, hogy szerepükben meg tudták-e a játékba lépők valósítani, amit szerettek volna. Az Ajkay-féle verzióban annak mentén ment a feldolgozás, hogy miért éppen azt a szerepet választották vagy kapták a résztvevők, amit. Mindkét kérdés a csoporttagok egyéni élettörténetébe illeszti a csoport eseményeit, tehát az intrapszichés felé indítja az interpretációt.

Amennyiben szociodráma ülésen lennénk, a közös jelentés megszületése érdekében érdemes ügyelni arra, hogy a folyamatanalízis semmilyen körülmények között ne maradjon el az ülés végéről az egyéni tanulságok levonása, a csoportülésen belül viszont el is maradhatna. Sőt, a Szociodráma Múhelyünk egy része által képviselt szigorúbb szociodráma-felfogás szerint el is kell, hogy maradjon, hiszen olyan belső folyamatokat indíthat el, illetve tehet nyilvánossá a kérdés, amelyre egy szociodráma ülésen a résztvevők nem szerződtek.

\section{A történet alakulását befolyásoló vezetői intervenciók: időugrás, új szereplő ajánlása, sorsfordító esemény bejelentése}

A Mérei-féle játékok fontos eleme, hogy a szabad interakciókat olykor a történet menetébe való vezetői beavatkozás alakítja. Ennek három példáját láttuk a vizsgált eseményeken: az időugrást, új szereplő ajánlását, illetve sorsfordító esemény bejelentését. 


\section{TEMATIKUS TANULMÁNYOK - Pszi-komplexum}

Időugrás mind a Mérei Zsuzsa-féle, mind az Ajkay-Kökény által vezetett ülésen megjelent. Ennek technikája, hogy a folyamatokat meggyorsítandó az időt a vezető egy beszólással „előbbre tekeri”. Azaz arra kéri a résztvevőket, hogy az eseményeket folytassák néhány órával, nappal vagy akár évvel később.

Új szereplő ajánlása csak az Ajkay-Kökény-féle eseményen jelent meg: itt az egyik vezető a játékban nem lévő csoporttagoknak ajánlotta, például a rendőr szerep színrevitelét, amelynek a megjelenése egyszerre növelte volna a fenyegetettség érzését a színen és biztosította volna egy fontos társadalmi szereplő, a náci hatalom helyi intézményesített kiszolgálóinak megjelenését.

Mindkét technika azt szolgálja, hogy a vezető valamilyen módon meggyorsítsa, új perspektívába helyezze a csoport által spontán felvitt eseményeket.

A szociodramatista szempontjából ez a módszer nem csak technikai okból fontos (nyilván segíti a dráma kibontakozását, az időkeretek kontrollálását), hanem jó lehetőséget adhat a társadalmi jelentés létrejöttének biztosítására is, hiszen segítségükkel tágabb, illetve más perspektívát kínálhat a vezető. E technikákkal tehát a második részben felsorolt szintek megjelenése és a társadalmi intézményrendszer horizontális megrajzolása is biztosítható.

Ha tehát például az időugrás történelmi távlatokba helyezi a jelen eseményeit, úgy a transzcendensnek nevezett szintre helyezi a jelen történéseit a vezető, míg a hatalom reprezentánsának behozatalával egyértelműen segíti a társadalmi dinamikák felőli értelmezés megindulását. Ha azonban ezt még tudatosabban teszi a szociodráma-vezető és ügyel arra, hogy ténylegesen az összes társadalmi szereplő a színre kerüljön, akkor könnyen megszülethet egy olyan játék, amelyben nem csak a csoporttagok számára érzelmileg előtérben lévő szerepek, pozíciók jelenjenek meg, hanem az a társadalmi valóság, amely, még ha sokszor áttételesen is vagy távolabbról a résztvevők számára közvetlenül nem látható módon, de hatással van az adott szituáció alakulására.

\section{A jelentéskonstrukciónak fókuszt nyújtó vezetői beavatkozások: instrukciók, ismétlés, reflektor}

A Mérei-féle drámák másik fontos eleme, hogy a csoport résztvevőit, illetve a szereplőit viszonyok tisztázására szólítják fel a vezetők: „Az egymáshoz való viszonyokat tisztázzátok!”.

Az instrukció lényege, hogy a csoportban zajló dinamikák kerüljenek a fókuszba. Ez a cél a buggyantásnál, a játékok alatt, illetve a folyamatra reflektáló zárókörben is.

A fenti instrukció tehát akár az ülés első fázisában, az ún. buggyantás folyamatában is elhangozhat, hiszen ott a cél, hogy a résztvevők az itt és mostban megszülető közös témájukat találják meg, amelynek integráns része a köztük lévő dinamika. 


\section{TEMATIKUS TANULMÁNYOK - Pszi-komplexum}

Esetünkben azonban a szerepfelvétel után Ajkay Klára explicite kérte erre a játékban résztvevőket.

A szociodramatistákat ez az instrukció segíti a társas szint megjelenítésében és fókuszban tartásában.

A vezető azonban élhet mind a buggyantás folyamat alatt, mind a játékvezetésben, mind a zárókörben olyan eszközökkel, amelyek instruálás nélkül vonnak a figyelem középpontjába bizonyos jelentéseket. Az ismétlés eszköze a protagonista központú pszichodrámában is jól ismert. Funkciója, hogy minden interpretáció nélkül bizonyos, a vezető által fontosnak ítélt jelentésekre irányuljon a figyelem. A Mérei-féle vizsgált esetekben a buggyantás folyamata alatt láttuk mindkét alkalommal, hogy a vezető bizonyos elhangzott fordulatokat megismétel, akár hozzátéve, hogy „ott tartunk, hogy...” Van azonban a reflektor nevű, a játék menete alatt alkalmazható technika, amely szintén interpretáció nélkül von fókuszba fontosnak ítélt történéseket. Lényege, hogy az események párhuzamosságát letiltja, bizonyos színhelyek eseményeit kihangosítja, és az egész számára elérhetővé teszi. Funkciója teljesen gyakorlati is lehet: hiszen fontos, hogy tudják egymásról a résztvevők, hogy a különböző helyszíneken mi zajlik. Ajkay Klára a vizsgált eseményen minden helyszínt reflektor alá vett, de kisebb csoport esetén erre nem feltétlen van gyakorlati okokból szükség.

A fenti három technika fontos tehát ahhoz, hogy megosztottá, közössé váljanak a jelentések, amelyekre e technikák esetén kivétel nélkül a vezető tesz ajánlatot. (Feltételezzük, hogy a hamis, a csoport által nem jóváhagyott ajánlatokat úgyis figyelmen kívül hagyja a csoport.)

Tudni kell, hogy a vezetői ajánlatoknak a csoportdinamika miatt mindig kiemelt jelentése van, így valójában a vezető a kiemelésekkel akkor is értelmez, ha nem interpretál. Jó, ha a fent rögzített elvek szerint a szociodramatista kellő tudatossággal képes használni ezeket az eszközöket.

\section{Összegzés}

Cikkünkben megmutattuk Mérei Ferenc csoportcentrikus pszichodrámájának esetén keresztül, hogy Magyarországon a politikai közeg hogyan tehette lehetővé a pszichológiai módszerek és gondolkodás megerősödését, miközben elterelte a figyelmet ugyanezen technikák lehetséges társas és társadalmi közegben való alkalmazhatóságáról. Érdemes lehet elgondolkodni - a fenti elemzés példáján -, hogy a különböző bevett és jól kidolgozott pszichológiai módszerek hogyan mozdíthatóak el az individuális szemlélettől a társadalmi fókusz felé.

Megállapítottuk azt is, hogy a szociodráma differentia specifikájának rögzítése közben kialakult előfeltevéseinknek (közös társadalmi jelentés születése) a Mérei-féle csoportcentrikus pszichodráma kevés transzformációval, tudatos szociodrá- 


\section{TEMATIKUS TANULMÁNYOK - Pszi-komplexum}

ma-vezetői szerepbelépéssel megfeleltethető. A közös társadalmi jelentés születésének alapkritériumát további tanulmányokban tervezzük kifejteni.

Fontos leszögezni azt is, hogy amennyiben a Mérei-féle csoportcentrikus pszichodrámát szociodrámaként alkalmazzuk, akkor az a sok szociodráma-típus közül csak az egyik lehetséges, viszont szerencsére elég jó hagyománnyal rendelkezik, átadható rendszere van.

A másik, szintén továbbgondolandó kérdésünk, hogy milyen céllal, mikor érdemes éppen ezt a fajta szociodrámát alkalmazni. E kérdés megválaszolásához sokat segíthet az a viszonylag teljes funkciólista, amelynek kialakítását még Szociodráma Mühelyünkben nem fejeztük be. Ennek ellenére az már jól látszik, hogy például a Mérei alapú szociodráma tudományos felmérés céljára nem alkalmazható, de például szervezetfejlesztésre, társadalmi kontextualizálás céljából vagy éppen közösségi vízióépítő funkciókra alkalmas lehet.

\section{Irodalom}

Ajtony Á. (2006): Adalékok a pszichodráma történetéhez. In: Borgos A. - Erős F. Litván Gy. (szerk.): Mérei élet-mű. Tanulmányok. Új Mandátum Könyvkiadó, Budapest.

Bagdy E. (2006): Pszichodráma műhelycsoportunk (M. Cs.) teljesítményei. In: Borgos A. - Erős F. - Litván Gy. (szerk.): Mérei élet-mű. Tanulmányok. Új Mandátum Könyvkiadó, Budapest.

Blatner, A. (2011): Reflections on sociodrama. In: Wiener, R. - Adderley, D. -Kirk, K. (eds.): Sociodrama in changing world. Sociodrama and Actions Methods Training, London, 47-60.

Erdélyi I. (2006): Mérei Ferenc pszichodrámája. In: Borgos A. - Erős F. - Litván Gy. (szerk.): Mérei élet-mű. Tanulmányok. Új Mandátum Könyvkiadó, Budapest.

Gergely S. (2018): Kié a pszichológia? Kinek és miértvan szüksége a kritikai pszichológiára? http://ujegyenloseg.hu/kie-a-pszichologia-kinek-es-miert-van-szuksege-a-kritikai-pszichologiara/ (Letöltés dátuma: 2019. 04. 21.)

Kovai M. (2016): Lélektan és politika. Pszicho-tudományok a magyarországi államszocializmusban 1945-1970. L'Harmattan, Budapest.

Krüger, R. (2017): A zavarspecifikus pszichodráma-terápia. L'Harmattan, Budapest.

K. Horváth Zs. (2006): Szexuál-lélektani szubkultúra az ötvenes évektől. Vázlat a Törzs keletkezéséről és politikai szocializációjáról. In: Borgos A. - Erős F. - Litván Gy. (szerk.): Mérei élet-mű. Tanulmányok. Új Mandátum Könyvkiadó, Budapest. 
www. metszetek.unideb.hu

\section{TEMATIKUS TANULMÁNYOK - Pszi-komplexum}

Lindqvist, M. (2005): Religion and the spirit. In: Holmes, P. - Karp, M. - Watson, M. (eds.): Psychodrama since Moreno. Innovations in theory and practice. Routledge, London - New York, 137-152.

Mérei F. (1989): A pszichológiai labirintus. Fondorlatok és kerülőutak a lelki életben. Pszichoteam, Budapest. 